concerts and theatrical performances, and it was here that the installation of the Queen Mother took place. Those who were responsible for the planning of this are to be congratulated.

Of the seventy full-time students at the College in July 1957, fourteen are members of the Faculty of Science, taking the B.Se. (General) course in science of the University of London. Fifty-four of the students are resident; eight, including one woman, are African and there is one Indian woman student who is non-resident. Of the subjects coming under the Faculty of Science, chemistry is the most frequently studied, having about twice as many students as other subjects. Botany, mathematics, physics and zoology enrol approximately the same numbers.

Of the nine professors who have at present taken up their appointments, five are in the Faculty of Science, three are in the Faculty of Arts (African studies, English and education), while a special appointment as director of the Institute of Education is held by Prof. B. A. Fletcher. The library, which already contains nearly 16,000 volumes, is regularly receiving 450 journals.

As has been said more than once, in a country where racial tension can arise, the position of a multi-racial university is especially important. The declared aim of the Central African Federation is a partnership between the races, European and nonEuropean, and to the attainment of this ideal the University College of Rhodesia and Nyasaland, with the goodwill of the people and Government support, will make a most important contribution. In the words of the motto of the University College, 'Wisdom builds the house of life'. Wisdom has indeed gone to the founding and fostering of this new University institution, and to the principal, Dr. Walter Adams, and to all his staff, universities all over the world will look for the results of a most important educational experiment during the coming years.

F. G. YOUNG

\title{
OBITUARIES
}

\section{Dr. Harold Thompson}

ONLY a few of the ex-Servicemen who entered fishery research in 1920 had survived as soldiers from the beginning of the war-period 1914-18, and among them was Capt. Harold Thompson, of the Royal Field Artillery, who had served five years in France and had twice been mentioned in dispatches. His first fishery research was on the great number of haddock scales collected by the Scottish research vessels. They made very good sense when handled by Thompson, who was soon able to forecast with some accuracy the fortunes of the important North Sea haddock fishery. The basis was the relative abundance of annual broods of fish, as shown by catches of ages below those at which they exerted their full commercial weight. Thompson's success convinced us all that the Norwegian methods need not be confined to their own fisheries, where extreme annual fluctuations were the rule, and forecasting became, after Thompson's work, one of the standard aims of fishery research everywhere.

Harold Thompson was born on October 12, 1890 . He was the son of William Thompson, who was headmaster of the Middle School, Aberdeen. After graduating in arts in 1912, he taught for one year in Perthshire and returned to the University of Aberdeen with the intention of taking a science degree. On the outbreak of war, however, he enlisted in the Gordon Highlanders and was later promoted to commissioned rank in the artillery.

In 1920 Thompson obtained special distinction in chemistry and zoology for his B.Sc. degree at Aberdeen and, after a short period assisting in the Biochemistry Department in the University of Edinburgh, was appointed a junior naturalist by the Fishery Board of Scotland in 1921. His doctorate was awarded for a thesis on the local growth-rates, age analyses and migrations of the haddock. He did not, however, relinquish his interest in systematic zoology. Although he was to carry for most of his working life the responsibility of a director, he yet found time to make substantial additions to know. ledge of the tunicates.
For some years the Government of Newfoundland, then proudly calling itself Britain's oldest Dominion, had been anxious to know more about the fish on which the economy of the island mainly depended. In 1930 Thompson undertook a survey of the fisheries, and in 1931 he was made the first director of fisheries research in Newfoundland. $\mathrm{He}$ built up an organization based on Bay Bulls near St. John's and used a trawler for research purposes, making not only the usual ecological surveys but also attempting some codification of the undoubted relationship between cod catches and temperature, which had been explored first by Commandant Beaugé of the French Fisheries Service. Thompson gave, with due reservations, something of a guide to favourable temperatures in different regions and for different sizes of cod, and this provided a basis for more recent work in other parts of the world where there is mixing of Arctic and Atlantic water. Sometimes the relationship is as it were accidental, depending really on the movement of the water-masses ; sometimes it is vital, and I think that Thompson fully realized both possibilities.

In 1937 Thompson was again to found a new fisheries laboratory, this time at Cronulla, near Sydney, with subsidiary stations in other parts of Australia. He attracted and selected staffs of high quality, and a substantial bulk of excellent work has come from his foundations. He retired from the post of chief of fishery investigations in December 1954, and the library at Cronulla is named after him.

In appearance, Thompson was spare, dark and keen looking. He looked what he was-penetrating, critical and reliable. $\mathrm{He}$ could not have achieved what he did without a firm intention amounting almost to enthusiasm; but he also gave full measure of scepticism where it was required, and accepted without apparent concern the resulting ingratitude. $\mathrm{He}$ engendered the firm respect and affection of those who appreciated his highly tempered quality. Thomp. son died in Edinburgh on May 29, and leaves a widow and son who will have all our sympathy.

Michael Graham 